LASU Journal of Employment Relations \& Human Resource Management $\quad$ Volume 1. No. 1, 2018

\title{
AN EVALUATION OF THE EFFECTS OF REGULATORY AGENCY ON PROJECT SUCCESS IN LAGOS STATE
}

\author{
OLATEJU, Olawale Ibrahim(PhD) \\ Department of Management Technology, Faculty of Management Sciences, Lagos State University \\ olawale.olateju@lasu.edu.ng \\ DOI: 10.36108/ljerhrm/8102.01.0141
}

\begin{abstract}
Literature on regulation concentrated on the analysis of the policy on regulating agencies and the rules and guidelines associated with the policies. The effects of regulation on specific firm or industry have not been fully discussed. This study assesses the situation by examining the effects of regulation on project success in pure water production. Survey research design was adopted for this study. Copies of the questionnaire used for the study were administered to members of staff of NAFDAC Lagos State, owners of pure water companies in Lagos state and pure water sellers. Members of staff of NAFDAC, Lagos State, were selected using stratified random sampling technique and purposive sampling technique, while pure water sellers were selected using judgmental sampling technique. The questionnaire for this study was validated using content validity. The reliability of the questionnaire was also confirmed by determining the reliability correlation coefficients of the data collected at two different periods, which was equal to 0.851. The data collected for the study were presented using charts, tables, percentages and frequencies, while the stated hypotheses were analysed with the aid of correlation analysis and regression analysis. The findings revealed that $85 \%$ of the variation in product quality is accounted for by consumer protection policies; $72.6 \%$ of the success recorded in operations and activities of pure water manufacturers is accounted for by efforts of NAFDAC regulation; and that there is a significant relationship between regulatory processes and client satisfaction $(r=0.775, p=0.000)$. Based on these findings, the study therefore recommended that NAFDAC should partner with state governments to create State-NAFDAC so that the gains will permeate all the nooks and crannies of the country and that pure water producers must have project management skills and knowledge as they carry out their work in the community.
\end{abstract}

Key words: Project success, Pure water,Regulatory agency,production.

\section{Introduction}

Regulation is the key instrument for economic governance; it is intended to correct market failures, affect the economic behaviour of agents in ways that will increase economic welfare and thereby support market efficiency and economic growth. Regulatory reform is a set of measures that have the mutual objective of reinforcing the regulatory environment. These include regulation policy, regulatory institutions and regulatory processes (Organisation for Economic \& Corporation Development [OECD], 2011). Regulation is an essential policy instrument that affects citizens' behaviour. It simplifies dealing with challenging economic, social and environmental problems. A well-defined regulation comprises of a complex chain of interventions, interactions, and impacts. Regulation seeks to change behaviour in order to produce desired outcomes. When regulation is initiated from a good intention to advance the public interest, expected outcomes will be achieved. A regulation is effective when it solves the problems that stimulated government to adopt it in the first place (Treasury Board Canada Secretariat, 2009).

Regulatory measures can promote economic and social growth but can also generate significant economic and social cost. Regulations include costs; firms are forced to waste resources that could be invested in more productive activities, in order to comply with regulations. This harms the growth and welfare of the whole economy. Thus, it is important that regulations are well planned, justified, and enforced.

In recent times, organizations undertakings are becoming more project-based, the consequence is that organization tends to divided routine work into smaller projects in order to quickly achieve organizational goal. Good controlling of these projects is critical if the organization is going to succeed. Directing all the projects effectively will ensure we are doing the right projects. The development in new information has led to the complexities of projects since projects encompass the latest developments. Today, most companies focus on project management, as it helps in achieving project objectives. It is imperative as it applies administrative process and has its techniques that give managers good opportunities to succeed in accomplishing aims.

Like other developing nations in the world, Nigeria is faced with the problem of providing satisfactory food and drug supply for its citizens. This is because food and drug have been identified worldwide as a biological and economic and political weapon. In acknowledgement of the significance of food and drug safety as an important factor for achieving high level of health for all Nigerians, the government launched the National Policy on Food Hygiene and Safety as an integral part of the Nigerian National Health Policy (Omotayo, \& Denloye., 2002). 
In line with the above school of taught this study examines the role of regulatory agency on project success by assessing the function of the national agency for food and drug administration control on pure water business.

\section{Historical Background of NAFDAC}

NAFDAC is a parastatal of the Federal Ministry of Health and was instituted on January 1, 1994. NAFDAC was established in response to the decision of the World Health Assembly in 1988 that in order to fight the threat that fake drug poses to global health, countries should establish a programme for the prevention and detection of fake pharmaceutical products. In December 1992, NAFDAC was inaugurated under the chairmanship of Ambassador Tanimu Saulawu. The supporting law (Decree No. 15, 1993) was signed into law in January 1993 (Nigeriafirst.org, 2006). NAFDAC regulatory agency has set the standards through which other public establishments could be judged. The study of NAFDAC is important as the agency has set the standard for assessing performance of public institution in Nigeria (Adetuyi, 2006). It was interesting to know that the world's foremost anti-corruption body found in a Nigerian an exemplary person in public service worthy of global emulation known as Dora Akunyili (Adetuyi, 2006).

\subsection{Statement of the Problem}

Regulatory interventions in a market is an issue of critical importance in modern economies. While the level of regulation varies across countries, it is commonly accepted that some degree of regulation is essential for a proper functioning society and economy. However, improving productivity is a long-term challenge and it takes time for workers, businesses and consumers to respond to structural economic reforms (Ayininuola \& Olalusi, 2004). Policy makers and the public typically care little about the animating problem underlying a regulation; they do not generally accept solving a problem at any cost.

Current literatures on regulations concentrated on the analysis of the policy of regulating agencies and the rules and guidelines associated with the policies. The dimensions of these studies did not highlight the effect of regulatory agency on specific firms or industry. Most of these discussions centered on regulation and control, deregulation and the concept of red-tape. This study has identified this gap and as such assesses the effects of the regulatory agency on project success, using pure water production.

\subsection{Objectives of the Study.}

The main objective of this study is to examine the effects of regulation on project success using pure water production. The specific objectives are to;

1. Examine the effects of consumer protection policies on product quality.

2. Assess the efforts of NAFDAC in regulating the operations and the activities of pure water production.

3. Examine the relationship between regulatory processes and customer satisfaction in Nigeria.

\subsection{Research Question}

1. What effect do consumer protection policies have on product quality?

2. What efforts does NAFDAC make in regulating the operations and activities of pure water production?

3. What relationship exist between regulatory processes and customer satisfaction in Nigeria?

\subsection{Research Hypotheses}

1. Consumerprotection policies do not have effect on product quality.

2. NAFDAC make a significant effort in regulating the operations and activities of pure water production.

3. There is no significant relationship between regulatory processes and customer satisfaction in Nigeria.

\section{Literature Review}

\section{Theoretical Framework}

\section{Public Interest Theory}

Public Interest Theory is an economic theory first developed by Arthur Cecil Pigou (Hantke-Domas, 2003) that holds that regulation is instituted in response to the demand of the public for the correction of ineffective market practices. This theory assumes that markets are extremely fragile and apt to operate very inefficiently (or inequitably) if left alone. The government is assumed to be a neutral mediator.

The public interest view holds that governments regulate an institution to facilitate the efficient functioning of such an institution by ameliorating market failures, for the benefit of broader civil society. In food and drug 
sector, the public interest would be served if the system allocated resources in a socially efficient manner (HantkeDomas, 2003) and performed well other functions of finance (Levine, 1997)

\section{Conceptual Framework}

\section{Project and Project Management}

A project is a complex, non-repetitive effort constrained by time, budget, resources, and performance specifications designed to meet customer needs (Gray \& Larson, 2008). It can be considered to be the achievement of a specific objective, which involves a series of activities and tasks that consumes resources. It has definite start and end dates. The project is focused on defining and selecting an activity which will benefit the company.

Project management on the other hand is the process of controlling the achievement of the project objectives; a set of tools, techniques, and knowledge that, when applied, helps to achieve the scope, cost and time objectives of the project (Charvat, 2003). Using the already-established organizational structures and resources, it controls the project by using a group of tools and techniques, without disturbing the operations of the company. The function of project management includes: the definition of work requirement, the establishment of the extent of work, to allocate the resources required, to plan the execution of the work, to monitor the progress of the work and to adjusting deviations from the plan. Project management is orientated towards planning and control. This is the level of the short-term life of the project establishment and delivery. Once delivery is achieved the management will cease. An entirely new different form of management will then establish the operation and control of the project use.

Project managers can use different techniques and tools that are useful to manage projects efficiently such as network activity diagram, bar charts, macro and micro cost estimation approaches and resource scheduling techniques, etc. The use of these techniques and tools can lead to better chance of project success. Today, emphasis on an all-encompassing project management process is the focus of all project effort towards the strategic plan of an organisation and reinforces control of both the project management techniques and tools, and the interpersonal skills necessary to plan successful project completion (Clancy,2008).

\section{Project Success}

The definition of a project suggests that there is a focus towards higher and long-term goals. Important parameters within the goals are return on investment, competition and market ability. The project success factors are highlighted in the table below:

Table 1: The project success factors and outcomes of project management success

\begin{tabular}{|c|c|c|}
\hline Project success factors & $\begin{array}{l}\text { Outcomes of } \\
\text { management }\end{array}$ & $\begin{array}{l}\text { Factors which may cause the project } \\
\text { management to fail. }\end{array}$ \\
\hline $\begin{array}{ll}\text { - } & \text { a realistic goal } \\
\text { - } & \text { competition } \\
\text { - } & \text { client satisfaction } \\
\text { - } & \text { a definite goal } \\
\text { - } & \text { profitability } \\
\text { - } & \text { third parties } \\
\text { - } & \text { market availability } \\
\text { - } & \text { the implementation process } \\
\text { - } & \text { the perceived value of the } \\
& \text { project. }\end{array}$ & 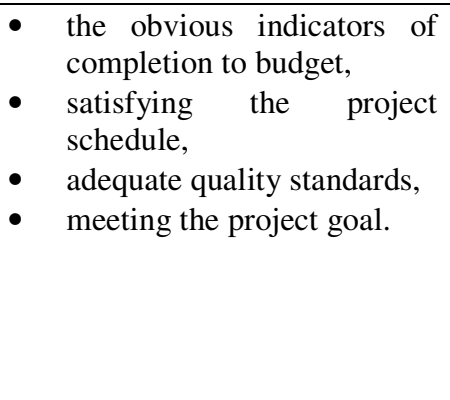 & $\begin{array}{l}\text { - } \text { inadequate basis for project; } \\
\text { - } \quad \text { wrong person as project manager; } \\
\text { - } \text { top management unsupportive; } \\
\text { - } \text { inadequately defined tasks; } \\
\text { - lack of project management } \\
\text { - techniques; } \\
\text { - } \text { management techniques mis-used; } \\
\text { - } \quad \text { lack of commitment to project. }\end{array}$ \\
\hline
\end{tabular}

\section{Source: Attarzadeh and $\mathrm{Ow}(2008)$}

Existing research show that when one or more projects are started, some important issues need to be considered to achieve project success (Coley, 2007). Some of these issues are planning with a commitment to complete the project, appointment of a skilled project manager, defining the project adequately, correctly planning the tasks in the project, ensuring effective communication and information flows and accommodating employees' personal goals with performance.

Coley (2007) discussed the different tools available to a project manager to achieve project success. These include work breakdown structures, client information sheets and project charter, among others. The early development of 
strategies, philosophies and methodologies of project implementation early enough has been stressed by Kumar (2007) as the most essential factor in achieving success. He suggested that by gathering enough site information and of project constraints; it is possible to tailor methods which are specific to a certain situation. Such welldefined strategies will help in providing a satisfying and successful implementation of a project.

Table 2: Project issues, description and activities.

\begin{tabular}{|c|c|c|c|}
\hline & Issues & Description & Activities \\
\hline 1 & Project focus & Time, budget and quality & $\begin{array}{l}\text { Focused on achieving these broad } \\
\text { goals. }\end{array}$ \\
\hline 2 & Planning & $\begin{array}{l}\text { Engage in planning - detailed and } \\
\text { systematic. }\end{array}$ & Planning and preplanning. \\
\hline 3 & Sense of urgency & $\begin{array}{l}\text { Limited time, money, and other } \\
\text { resources }\end{array}$ & $\begin{array}{l}\text { Regular status checks, meetings, } \\
\text { and reminders } \\
\text { are crucial. }\end{array}$ \\
\hline 4 & $\begin{array}{l}\text { Use a time-tested, proven project } \\
\text { lifecycle }\end{array}$ & $\begin{array}{l}\text { Use standard models to build into } \\
\text { project plans. }\end{array}$ & Identify the best project life cycle. \\
\hline 5 & $\begin{array}{l}\text { Visualised and communicated } \\
\text { invivid detail }\end{array}$ & Avoid vague descriptions. & Focused in the same direction. \\
\hline 6 & Evolve gradually to succeed & $\begin{array}{l}\text { Involvement of users in cost and } \\
\text { time estimation and risk } \\
\text { management. }\end{array}$ & Maintain a controlled evolution. \\
\hline 7 & $\begin{array}{l}\text { Clear approvals and sign-off by } \\
\text { sponsors }\end{array}$ & Clear approval points. & Examine and approve. \\
\hline 8 & Fight for time to do things right & Do it right the first time & $\begin{array}{l}\text { Demonstration and why it is } \\
\text { necessary? }\end{array}$ \\
\hline 9 & Matched by equivalent authority & Project outcomes & $\begin{array}{l}\text { Acquire and coordinate resources, } \\
\text { request. }\end{array}$ \\
\hline 10 & $\begin{array}{l}\text { Project sponsors and } \\
\text { stakeholders } \\
\text { must be active participants, not } \\
\text { passive customers }\end{array}$ & $\begin{array}{l}\text { Most project sponsors and } \\
\text { stakeholders rightfully demand } \\
\text { the authority to approve project } \\
\text { deliverables, either wholly or in } \\
\text { part. }\end{array}$ & $\begin{array}{l}\text { Helping to define deliverables. } \\
\text { Keeping the project moving. }\end{array}$ \\
\hline 11 & Acquire the best people & $\begin{array}{l}\text { Get the most skilled, experienced } \\
\text { and best qualified }\end{array}$ & Identify the right team members. \\
\hline 12 & Actively set priorities & Strategies, establishes criteria. & $\begin{array}{l}\text { Choose the right leader to prevent } \\
\text { multi-project log jams. }\end{array}$ \\
\hline
\end{tabular}

Source: Attarzadeh and $\mathrm{Ow}$ (2008)

\section{Regulation}

Regulations are rules established by government and backed up by some negative threat of consequences in form of penalties. Often directed at businesses, regulations can also take aim at non-profit organizations, other governmental entities, and even individuals. Regulations can also derive from any number of institutional sources - parliaments or legislatures, ministries or agencies, or even voters themselves through various kinds of plebiscites. Given their variety, regulations can be described using many different labels: constitutions, statutes, legislation, standards, rules, and so forth (Coglianese, 2012)

\section{Characteristics of effective regulation}

The following are the characteristics of an effective regulation:

- well-specified regarding rationale and objectives;

- well-integrated with existing and other regulations to avoid duplication;

- outcomes based - or at least not prescribed technological solutions

- notice and frequent engagement with target businesses and other stakeholders;

- long-term and consistent commitment to the regulatory form and purpose;

- minimizing administrative and compliance costs subject to achieving the regulatory purpose;

- demonstration of clear monitoring and enforcement processes that allows parties to be fully aware of the compliance requirements, sanctions and penalties;

- a risk-based compliance and cooperative approach to regulatory enforcement (rather than sanctions) designed to build trust and the incentives for long term innovation. 
A recent study published by the Network of European Environment Protection Agencies (2007) adopted an alternative approach and set out what it saw as the barriers to 'good' environmental regulation within the EU. The Network provides a checklist to enable relevant barriers to be identified when formulating new environmental regulation.

Table 1 Checklist for assessing regulatory quality According to the OECD and other experts, regulations that conform to best practice design standards are characterised by the following seven principles and features.

\begin{tabular}{|c|c|}
\hline $\begin{array}{l}\text { Minimum necessary to achieve } \\
\text { objectives }\end{array}$ & 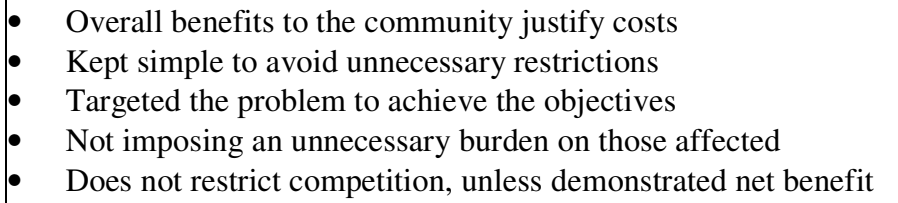 \\
\hline Not unduly prescriptive & $\begin{array}{l}\text { Performance and outcomes focused } \\
\text { General rather than overly specific }\end{array}$ \\
\hline Accessible, transparent and accountable & $\begin{array}{ll}\text { - } & \text { Readily available to the public } \\
\text { - } & \text { Easy to understand } \\
\text { - } & \text { Fairly and consistently enforced } \\
\text { - } & \text { Flexible in dealing with special circumstances } \\
\text { - } & \text { Open to appeal and review } \\
\end{array}$ \\
\hline Integrated and consistent with other laws & $\begin{array}{ll}\text { - } & \text { Addresses a problem not addressed by other regulations } \\
\text { - } & \text { Recognises existing regulations and international obligations }\end{array}$ \\
\hline Communicated effectively & $\begin{array}{ll}\text { - } & \text { Written in 'plain language' } \\
\text { - } & \text { Clear and concise }\end{array}$ \\
\hline $\begin{array}{l}\text { Mindful of the compliance burden } \\
\text { imposed }\end{array}$ & $\begin{array}{ll}\text { - } & \text { Proportionate to the problem } \\
\text { - } & \text { Set at a level that avoids unnecessary costs }\end{array}$ \\
\hline Enforceable & $\begin{array}{l}\text { - Provides the minimum incentives needed for reasonable } \\
\text { compliance } \\
\text { - } \quad \text { Able to be monitored and policed effectively }\end{array}$ \\
\hline
\end{tabular}

Source: Coglianese (2012)

\section{The Regulatory Market}

Regulations involve benefits that encourage certain groups to demand their adoption to obtain them. These include consumers, unions, firms, media and politicians, etc. Consumers ask for regulatory measures since they want to protect themselves from abuses by firms and market failures. These measures most times refer to prices of goods and services since prices significantly above marginal cost have negative impact on consumer's real income, increases producer welfare and reduces consumer welfare. Thus, consumers through regulations seek to prevent reductions in their welfare. Demand for regulations from unions includes labour protection, working hours reduction, wage increment and safety standards while from firms refers to measures in order to return sunk costs i.e. investments, to promote $R \& D$ and innovation (patent protection), removing barriers to entry, regulation of anticompetitive practices.

Regulations are beneficial to the society are introduced by governments. It is observed that a number of hinder this result into poor quality regulation.

\section{Regulatory Impact Analysis}

The ability to evaluate expected regulatory impacts on the business environment is essential. Regulatory Impact Analysis (RIA) is a tool used to enhance the understanding of economic, social or environmental impacts of regulation. It is a term used to define the process of scientifically analyzing the impacts of new or existing regulation, there by assessing impacts of new regulation (flow) as well as existing regulation (stock). RIA comes in various ways that reflect policy agendas of governments. Its objectives and applied technical methods in various in administrative processes in different countries and even among regulatory policy areas.

In summary, RIA is about:

- asking the appropriate questions during the policy-making process, and 
- facilitating the answers to those questions by providing stakeholders with an appropriate framework of institutions, tools and procedures.

\section{Nigerian Standard for Drinking Water Quality}

Nigerian Standard for Drinking Water Quality contains compulsory limits concerning constituents of water that are known to be hazardous to health and/or give rise to complaints from clients. The standard includes a set of processes and good practices required to meet the compulsory limits. In 2005, the National Council on Water Resources (NCWR) recognized the urgent need to establish acceptable Nigerian Standard for Drinking Water Quality because it was observed that the "Nigerian Industrial Standard for Potable Water" developed by Standards Organization of Nigeria and the "National Guidelines and Standards for Water Quality in Nigeria" developed by Federal Ministry of Environment did not receive a wide acceptance by all stakeholders in the country. Since water quality issues are health related issues, the Federal Ministry of Health, in agreement with the Standards Organization of Nigeria and working through a technical committee of key stakeholders developed this Standard.

\section{Figure 1. A causal map of regulation and its effects}

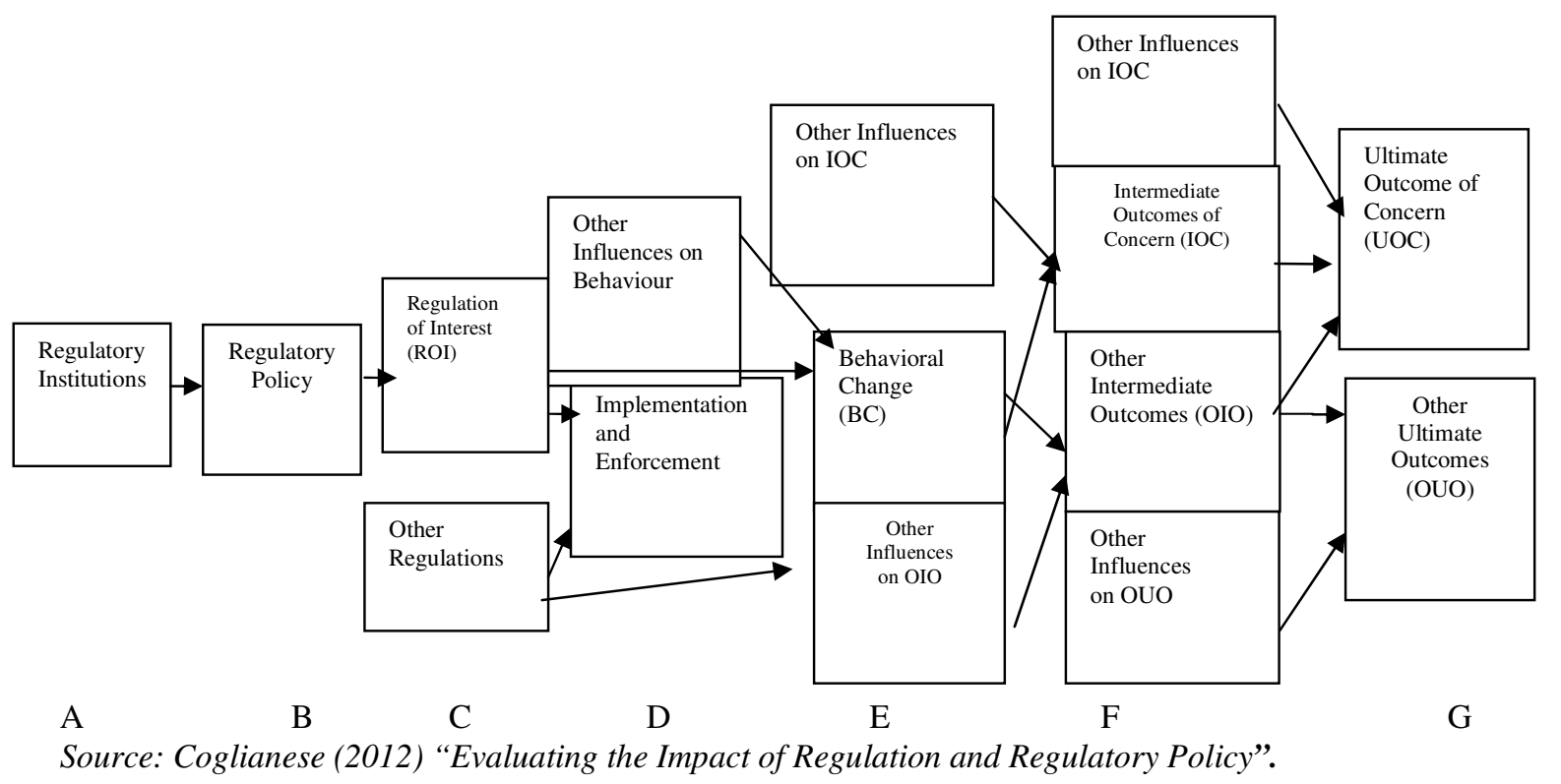

Impact of Regulatory Reform in Developing Countries

The aggregate level evidence on regulatory reform and economic growth is consistent with a priori expectations, showing a statistically significant and positive relationship between the quality of the regulatory environment and economic growth. Djankov, McLiesh and Ramalho (2006) find a statistically significant negative relationship between the regulatory business burden and economic growth.

Eifert (2009) finds a positive relationship between the regulatory governance and economic growth. His study suggested that well-managed poor countries gain from a broad push for streamlining regulations and procedures affecting business. Kirkpatrick, Parker and Zhang (2006) discovered that an effective regulatory environment provides regulatory credibility to the private sector and thereby enhances private investment. The results of the study showed that regulatory quality statistically significant and positively correlates to the private investment in infrastructure in developing countries. The empirical evidence of a positive correlation between the quality of the regulatory environment and macro-level investment and economic growth that improving the quality of regulatory governance is expected to significantly impact on economic performance.

However, this body of literature provides no guidance on the particular types of regulatory reform that are likely to be most effective. Indeed, where researchers have disaggregated the measure of governance into separate policy areas, the results have often failed to produce statistically robust evidence on the impact of individual reform measures. For example, when Eifert (2009) examines the impact of reform in five separate areas (business registration, contract enforcement, labor laws, property registration, and import-export) on investment and economic growth, the regression results are insignificant and, in many cases, have the wrong sign. 


\section{Research Methods}

Survey research design was adopted for the study. The population of the study comprises the members of staff of NAFDAC Lagos State, owners of pure water companies in Lagos state, pure water sellers and consumers in Lagos state. Questionnaires were administered to the selected members of staff of NAFDAC Oshodi using stratified sampling technique; selected members of staff of a pure water company in each of the five divisions in Lagos state using purposive sampling technique; and randomly selected customers from the five areas in Lagos state. A five-point Likert Scale with the ratings Strongly Agreed (5), Agree (4), Undecided (3), Disagree (2) and Strongly Disagree (1) was designed to establish the effects of regulations. The result of Cronbach's Alpha for the overall scale of the variables is 0.851 which is acceptable. Thus, the instrument was shown to be reliable.

\section{Results}

Demographic information of respondents

Tale 3: Sex of Respondents

\begin{tabular}{|ll|l|l|l|l|}
\hline & & & & & $\begin{array}{l}\text { Cumulative } \\
\text { Respondents }\end{array}$ \\
\hline NAFDAC & Male & 13 & 35.1 & 35.1 & 35.1 \\
& Female & 24 & 64.9 & 64.9 & 100 \\
& Total & 37 & 100.0 & 100.0 & \\
\hline Owners of pure water companies & Male & 75 & 72.8 & 72.8 & 72.8 \\
& Female & 28 & 27.2 & 27.2 & 100 \\
& Total & 103 & 100 & 100.0 & \\
\hline Sachet water sellers & Male & 74 & 91.4 & 91.4 & 91.4 \\
& Female & 7 & 8.6 & 8.6 & 100 \\
& Total & 81 & 100 & 100 & \\
\hline
\end{tabular}

Source: Field Survey, 2017

Table 3 shows that $35.1 \%$ of the respondents from NAFDAC were male while $64.9 \%$ were female; $72.8 \%$ of the owners of pure water companies were male while $64.9 \%$ were female; lastly, $91.4 \%$ of the pure water sellers were male while $8.6 \%$ were females; this implies that there are more male respondents than female.

\section{Analysis of the Respondents Responses on Regulation and Project Success}

Part 2 of the questionnaire aimed at determining the level to which respondents agree that project quality contributes to project success. Respondents were required to indicate their preference on the scale provided by ticking the appropriate box.

The tabulation of the raw scores for each construct is highlighted in the table below. The top two (strongly agreed and agreed) were collapsed into total agree while the bottom categories (strongly disagreed and disagreed) were collapsed into total disagree; to give an overall indication of the level of agreement on each statement. 
Table 4: Analysis of respondents' responses

\begin{tabular}{|c|c|c|c|c|c|c|c|c|}
\hline & \multirow[b]{2}{*}{$\mathrm{N}$} & \multicolumn{7}{|c|}{$\%$ of sample } \\
\hline & & $\begin{array}{l}\text { SA } \\
(\%)\end{array}$ & $\begin{array}{l}\mathrm{A} \\
(\%)\end{array}$ & $\begin{array}{l}\mathrm{UN} \\
(\%)\end{array}$ & $\begin{array}{l}\text { DA } \\
(\%)\end{array}$ & $\begin{array}{l}\text { SD } \\
(\%)\end{array}$ & $\begin{array}{l}\text { TOTAL } \\
\text { OISAGREE } \\
\%)\end{array}$ & $\begin{array}{l}\text { TOTAL } \\
\text { AGREE } \\
(\%)\end{array}$ \\
\hline \multicolumn{9}{|l|}{ PRODUCT QUALITY } \\
\hline $\begin{array}{l}\text { Executive Management } \\
\text { Support }\end{array}$ & 221 & 54.7 & 19.8 & 11.6 & 9.3 & \begin{tabular}{l|l}
4.7 & 1 \\
\end{tabular} & 14 & 74.5 \\
\hline Proper Planning & 221 & 36 & 27.9 & 12.8 & 16.3 & \begin{tabular}{l|l}
7 & 2 \\
\end{tabular} & 23.3 & 63.9 \\
\hline $\begin{array}{l}\text { Competent, Hard-Working } \\
\text { and Focused Staff }\end{array}$ & 221 & 53.5 & 26.7 & 10.5 & 4.7 & \begin{tabular}{l|l}
4.7 & 9 \\
\end{tabular} & 9.4 & 80.2 \\
\hline \multicolumn{9}{|c|}{ CUSTOMER SATISFACTION } \\
\hline $\begin{array}{l}\text { Regular status checks, } \\
\text { meetings, and reminders are } \\
\text { essential. }\end{array}$ & 221 & 36 & 40.7 & 9.3 & 10.5 & 3.5 & 14 & 76.7 \\
\hline $\begin{array}{l}\text { Project sponsors and } \\
\text { stakeholders must be active } \\
\text { participants, not passive } \\
\text { customers }\end{array}$ & 221 & 25.6 & 33.7 & 25.6 & 8.1 & & 8.1 & 59.3 \\
\hline $\begin{array}{l}\text { Project managers must be } \\
\text { trained to acquire the } \\
\text { necessary management skill. }\end{array}$ & 221 & 44.2 & 31.4 & 14 & 9.3 & 1.2 & 10.5 & 75.6 \\
\hline \multicolumn{9}{|c|}{ CONSUMER PROTECTION POLICIES } \\
\hline User Involvement & 221 & 44.2 & 19.8 & 15.1 & 9.3 & 11.6 & \begin{tabular}{|l|l|}
5 & 20.9 \\
\end{tabular} & 64 \\
\hline Project meets users' needs & 221 & 14 & 25.6 & 25.6 & 11.6 & 23.3 & 34.9 & 39.6 \\
\hline $\begin{array}{l}\text { Company in house training } \\
\text { and development }\end{array}$ & 221 & 39.5 & 27.9 & 9.3 & 12.8 & 10.5 & \begin{tabular}{l|l}
5 & 23.3 \\
\end{tabular} & 67.4 \\
\hline \multicolumn{9}{|c|}{ REGULATORY INSTITUTION } \\
\hline Realistic Expectations & 221 & 15.1 & 23.3 & 16.3 & 15.1 & 30.2 & \begin{tabular}{|l|l|}
2 & 45.3 \\
\end{tabular} & 38.4 \\
\hline $\begin{array}{l}\text { Clear Statement of } \\
\text { Requirements }\end{array}$ & 221 & 39.5 & 31.4 & 9.3 & 14 & 5.8 & \begin{tabular}{l|l}
3 & 19.8
\end{tabular} & 70.9 \\
\hline \multicolumn{9}{|c|}{ REGULATORY PROCESSES } \\
\hline Clear Vision and Objectives & 221 & 62.8 & 16.3 & 5.8 & 11.6 & 3.5 & \begin{tabular}{l|l}
5 & 15.1
\end{tabular} & 79.1 \\
\hline New technology & 221 & 33.7 & 24.4 & 11.6 & 12.8 & 17.4 & \begin{tabular}{l|l}
+30.2 \\
\end{tabular} & 58.1 \\
\hline Realistic time frames & 221 & 44.2 & 29.1 & 7 & 5.8 & 14 & \begin{tabular}{|l|l|}
+19.8 \\
\end{tabular} & 73.3 \\
\hline
\end{tabular}

Source: Field Survey 2017

\section{Interpretation of Respondents' Responses on Project Quality}

$74.5 \%$ of the respondents agree that executive management support affects the progress of a project and lack of executive input can put a project at a severe disadvantage; $63.9 \%$ of the respondents agree that Proper Planning is the main key to a successful project. Creating a project plan is the first thing to do when undertaking any kind of project; while $80.2 \%$ of the respondents agree that Competent, Hard-Working and Focused Staff members of an organization will help the organization succeed.

\section{Interpretation of Respondents' Responses on Customer Satisfaction.}

$76.7 \%$ of the respondents agree that regular status checks, meetings, and reminders are essential for project success; 59.3\% agree that Project sponsors and stakeholders must be active participants, not passive customers; while $75.6 \%$ agree that project managers must be trained to acquire the necessary management skill.

\section{Interpretation of Respondents' Responses on Consumer Protection Policies}

$64 \%$ of the respondents agree that User Involvement is very essential if a project must succeed, even when delivered on time and on budget, a project can fail if it does not meet users' needs. $39.6 \%$ of the respondents agree 
that Project meets users' needs while $67.4 \%$ agree that company in house training and development should be made compulsory in all water factories.

\section{Interpretation of Respondents' Responses on Regulatory Institution}

$38.4 \%$ of the respondents agree that NAFDAC have realistic expectations, while $70.9 \%$ agree that NAFDAC's statement of requirements are clear. This refers to the base level requirements. By creating an insignificant, the effect of change will be reduced. An added advantage is that project managers are better prepared to expressive the needs and priorities of the next phase of the project. Unsuccessful project is triggered by project scope changes, incorrect use of project methodology, major changes in the requirements and testing, and/or inspections are poorly done.

\section{Hypotheses Testing}

\section{Hypothesis One}

Consumer protection policies in Nigeria do not affect product quality.

Regression analysis was used to also test this hypothesis.

\begin{tabular}{|l|l|l|l|l|l|l|}
\hline Model & $\mathrm{R}$ & R Square & $\begin{array}{l}\text { Adjusted R } \\
\text { Square }\end{array}$ & $\begin{array}{l}\text { Std. Error of the } \\
\text { Estimate }\end{array}$ & F & Sig. \\
\hline 1 & $.922^{\mathrm{a}}$ & .850 & .849 & .47617 & 1007.724 & .000 \\
\hline
\end{tabular}

The model summary above shows the extent to which consumer protection policies in Nigeria affect product quality. The coefficient of determination $\left(\mathrm{R}^{2}=0.850\right.$, $\mathrm{p}$-value $\left.<0.05\right)$ shows that $85 \%$ of the variation in product quality is accounted for by consumer protection policies. This shows that consumer protection policies by NAFDAC in Nigeria affect product quality significantly.

\section{Hypothesis Two}

The efforts of NAFDAC in regulating the operations and activities of pure water manufacturers are not significant.

Regression analysis was used to also test this hypothesis.

\begin{tabular}{|l|l|l|l|l|l|l|}
\hline Model & $\mathrm{R}$ & R Square & $\begin{array}{l}\text { Adjusted R R } \\
\text { Square }\end{array}$ & $\begin{array}{l}\text { Std. Error of the } \\
\text { Estimate }\end{array}$ & F & Sig. \\
\hline 1 & $.852^{\mathrm{a}}$ & .726 & .724 & .67650 & 470.481 & $.000^{\mathrm{b}}$ \\
\hline
\end{tabular}

The model summary for the hypothesis above shows the extent to which the efforts of NAFDAC in regulating the operations and activities of pure water manufacturers are significant. The coefficient of determination $\left(R^{2}=0.726\right.$, p-value $<0.05$ ) shows that $72.6 \%$ of the success recorded in operations and activities of pure water manufacturers is accounted for by efforts of NAFDAC regulation. The efforts of NAFDAC regulatory body in regulating the processes and activities of pure water manufacturers are significant.

\section{Hypothesis Three}

There is no significant relationship between regulatory processes and customer satisfaction.

Correlation analysis was also used to test this hypothesis.

\begin{tabular}{|ll|l|l|}
\hline \multicolumn{4}{|c|}{ Correlations analysis } \\
\hline & Pearson Correlation & $\begin{array}{l}\text { Customer } \\
\text { Satisfaction }\end{array}$ & Regulatory processes \\
\hline \multirow{5}{*}{ Customersatisfaction } & Sig. (2-tailed) & & .775 \\
& $\mathrm{~N}$ & 221 & .000 \\
& Pearson Correlation & .775 & 221 \\
& Sig. (2-tailed) & .000 & 1 \\
Regulatory processes & $\mathrm{N}$ & 221 & 221 \\
\hline
\end{tabular}

The correlation table above shows that a high positive relationship exists between There is no significant relationship between regulatory processes and customer satisfaction $(r=0.775, p$-value $<0.05)$. This implies that there is a significant relationship between regulatory processes and client satisfaction. 


\section{Conclusion}

Regulation takes aim at discrete but varied problems. But far too seldom do policymakers get a chance to see how close they have come to hitting the bulls-eye. Governments need reliable indicators that will measure the full range of outcomes, positive and negative, caused by that regulation, and they need to analyse those indicators using careful research designs that either relies on randomized experiments or use sophisticated statistical techniques that can control for confounders to know whether a regulation works. The same is true to regulatory policy and regulatory management systems. Those rules, procedures and practices that govern the rule-making process itself are intended to improve regulators' decisions, and hence to deliver both substantive and process outcomes. Unfortunately, regulatory policies have until now been far too often recommended without serious evaluation to support them. They may well be justified, governments will need to evaluate the substantive outcomes of their regulations using the framework of indicators and research designs elaborated in this report. They also need to apply that same framework to evaluate the distinctive process outcomes that regulatory policy aims to achieve.

\section{Recommendations}

Drinking water producers must have requisite skills and knowledge as they carry out their work in the community. Their ability and knowledge must include project management and water safety and hygiene matters. Deliberate effort must be made to discourage a situation where some people will be exploiting people not only of their money but also in a manner that can pose danger to their health. All hands must be on deck to ensure that the water being circulated in the community is not contaminated at any form.

Other recommendations are:

1. NAFDAC oughtto partner with state governments to create State owned NAFDAC so that the achievements will permeate all corners of the country.

2. There should be meaningful co-operation with NAFDAC experts in different countries through regular teaching of staff. If this is done, then there will be a cross-fertilization of up-to-date ideas on scientific knowledge about the product to avoid contamination and laxity on the part of producers.

3. The government must ensure that Water manufacturers adhere strictly to good personal hygienic practices and undertake regular inspection and proper registration of all water production premises so as to protect the health of customers.

\section{References}

Adetuyi, D. O. (2006). The librarian, NAFDAC Oshodi Laboratory, in discussion with the author (Francis O. Ogbeide), December 11.

Attarzadeh, I., \& Ow, H. S. (2008). Management practices: The criteria for success or failure. Communications of the IBIMA, l(1), $234-241$.

Ayininuola, G.M., \& Olalusi, O. O. (2004). Assessment of building failures in Nigeria: Lagos and Ibadan case study. African Journal of Science and Technology (AJST) Science and Engineering Series 5(1):73-78

Charvat, J. (2003). Project management methodologies: selecting, implementing, and supporting methodologies and processes for project, New Jersey: John Wiley \& Sons, Inc.

Clancy, T. (2008). The Standish Group Report. Retrieved February 20, 2008, from http://www.projectsmart.co.uk/reports.html

Coglianese, C. (2012). Empirical analysis and administrative law. University of Illinois Law Journal, 1111-1137.

Coley, P. (2007). Why projects fail? Retrieved on Feb 27, 2015 from www.coleyconsulting.co.uk. Project fail,

Djankov, S., McLiesh, C. \& Ramalho, R. M. (2006). Regulation and growth. Economic Letters 92, 395-401.

Eifert, B.P. (2009). Do regulatory reforms stimulate investment and growth? Evidence from the doing business data 2003-07. Working Paper 159. Center for Global Development: Washington DC.

Gray, C. F., \& Larson, E. W. (2008). Project management. New York, NY,: McGraw-Hill/Irwin.

Haider, J.I. (2012). Impact of business regulation reforms on economic growth. Washington DC: World Bank.

Hantke-Domas, M. (2003). The public interest theory of regulation: Non-existence or misinterpretation? European Journal of Law and Economics, 15(2). 165-194.

Jalilian, H., Kirkpatrick, C., \& Parker, D. (2007). The impact of regulation in developing countries: A crosssectional analysis. World Development 35(1), 87-99.

Kirkpatrick, C, Parker, D, \& Zhang, Y.F. (2006). Regulatory impact assessment in developing and transitional economies: a survey of current practice. Public Money and Management 24(5), 291-297. 
Kumar, D. (2007). Developing strategies and philosophies early for successful project implementation. Project Management 7(3), 164-171

Levine, R. (1997). Financial development and economic growth: Views and agenda. Journal of Economic Literature, XXXV(June 1997). $688-726$.

Network of European Environment Protection Agencies. (2007). Barriers to good environmental regulation. $\begin{array}{llll}\text { Retrieved July } & 5, & 2017, & \text { from }\end{array}$ http://ec.europa.eu/environment/archives/better_regulation/conference_march07/pdf/barriers.pdf

Nigeria First (2006). The fight against fake drugs by NAFDAC in Nigeria. Retrieved July, $1^{\text {st }}, 2017$, from http://www.nigeriafirst.org/printer_315.shtml

Organisation for Economic Cooperation and Development (2011). Regulatory policy and the road to sustainable growth. $\quad$ Retrieved December $13, \quad 2017, \quad$ from https://www.oecd.org/regreform/policyconference/46270065.pdf

Omotayo, R. K. \& Denloye, S. A. (2002). The Nigerian experience on food safety regulations. FAO/WHO global forum of food safety regulators, Marrakesh, Morocco. Retrieved September, $2^{\text {nd }}, 2017$, from https://www.researchgate.net/publication/266471703_The_Food_Industry_in_Nigeria_Development_and Quality_Assurance.

Treasury Board of Canada Secretariat (2009). Handbook for regulatory proposals: performance measurement and evaluation plan, available at www.tbs-sct.gc.ca/ri-qr/documents/pmeppmre/n pmep-pmre-eng.pdf 